by Professor Young in the solar corona. The lines $\mathrm{C}$ and $\mathrm{F}$ having already been observed, the tiscovery of the line $G$ seems to render certain the existence of this gas in the Aurora. The common methods of interpolation were not available for computing the wave-lengths of column three, on account of the large interval between the lines. A curve was therefore constructed, in which vertical distances represented scale-readings, and horizontal distances the square of the reciprocal of the wave-lengths. This, by the formula of Cauchy, should be very nearly a straight line, giving, consequently, results of great accuracy.

EDWARD C. PICKERING

ON the evening of Monday, October 24, a very remarkable auroral display was observed in New York City. In the north at first was an obscure segment, low towards the horizon, surmounted by a pale glow of light. Later, this was replaced by an extensive manifestation of beautiful streamers.

But the most notable part of the phennmenon was a band of brilliant red light, varying in its different parts constantly throughout the evening, in brilliancy, definition, and breacth, but in general some ten degrees wide. It was seen early in the evening, and could be traced from within fifteen degrees of the horizon in the east and the west, extending entirely across the sky, south of the Zenith.

The position of this rosy band viewed from the south-east corner of the Central Park, was from $8 \frac{1}{4}$ to $8 \frac{1}{2}$ p.m., New York City mean time, about as follows.

In the east, just above the horizon, passing almost centrally, and diagonally through the figure of Cetzus, say between $\delta$ and $\zeta$ Ceti ; thence going westward it lay between Piscis occidentalis and $\gamma$ Aquarii, and between Altair and Delphinus, often expanding in width beyond these boundaries. Thence it extencled westward to the stars in the heads of Hercules and Serpentarius nearly to the horizon.

In all its splendid variations throughout the evening, it maintained its position in regard to the horizon of the observer standing in the locality before mentioned, the diurnal motion of the earth carrying the stars past it.

On the following evening the exhibition of this red band, in the same position, was at least equally pronounced; but without any decided boreal light, so far as I have noticed or learned.

I would also here mention the very brilliant display of variously tinted auroral streamers which engaged the admiration of members of the American Association for the Advancement of Science, as they returned by the steamer on the Hudson to the city of Troy, from their visit to Albany, from ten to eleven o'clock on the evening of Friday, August 19, 1870.

Honey Brook, Stanfordville P.O., New York

\section{Early Mentions of the Aurora Borealis}

Your correspondent, Mr. Earwaker, should have mentioned that the list of appearances of the A urora Borealis given in M. de Mairun's work is chiefly derived from another enumeration in Prof. Frobes's "Nova et Antiqua Luminis atque Aurorie Horealis Spectacula," Helmstadii, 1739. On reference to this list it immediately appears that it is very little to be relied upon for displays previous to the year $\$ 707$ or thereabouts. Some of the aupearances recorded rest on no good authority, others nere obviously meteoric; some occurred within the Arctic circles, others are entered twice over from inadvertence, or a neglect to allow for the difference of style; more than twenty are recorcled on the authority of the meteorological diary kept at Breslau by Grebner, who in fact says nothing more than that on those occasions the night was somewhat bright (sublustris). When the necessary deductions on thèse accounks have been made, it will be found that the infrequency of the phenomena prior to 1707 , and its extraordinary development since that date, are well-estab. lished facts. They are strongly insisted upon by M. de Mairan himself, who does not produce more than five instances of the aurora in France during the whole of the seventeenth century, and shows from the evidence of a missionary that it was unknown or forgotten in China until 1718 . All contemporary notices prior to about this period, attest the astonishment with which it was regarded.

From the following curious passage in Sirr's "Ceylon and the Cingalese" (vol. ii. p. Ir 7), it would appear that the aurora, or something resembling it, is occasionally visible in Ceylon :-

"There is a heavenly phenomenon which appears occasionally in Ccylon, callecl by the natives Buddha lights; this faintly resembles the Northem Lights, and is extremely resplendent. The priests declare this to be a sign of Buddha's displeasure when his followers have become sinful in the extreme, and that the light appears over the wilare, from whence the priests sup. pose the phenomenon to emanate, where those who have committed the sin which has aroused the god's anger last worshipped."

London, November 19

R. G.

IN many parts of Ireland a scarlet aurora is supposed to be a "shower of blood." In I854 while stationed at Bearhaven, County Cork, a scarlet aurora that then appeared was said to be the blood of the people that were slain at Balaclava. About two years ago, while driving between Oughterarel and Clifden, at two o'clock in the morning, there was a magnificent scarlet aurora (by far the most brilliant I ever saw), on which the carrdriver remarked, "I wonder, can that be the blood of the Americans?" The late aurora is said to be the blood of the Frenchmen.

In the old Annals showers of blood are recorded at different times, always in connection with a great battle or the murder of some great chief. The earliest I can remember is that of A.I. 688 , in the "Annals of Cloommacnoise," after a battle of the Leinster-men and Ossory-men (now in the King's County, but formerly in Munster), wherein Foylcher O'Moyloyer was slain. This battle and shower of blood in the "Annals of the Four" Masters," is said to have happened in the year A.D. 690 . These Annals also mention that butter was turned into the colour of blond and a wolf was heard to speak; while the Annals of Tighernach place the battle in A.D. 693, and say that the blood flowed in streans for three days and three nights. During the aurora I saw about two years ago, and the two nights that the last aurora was seen here, the lakes and rivers looked to be full of blood. Therefore I should imagine the aurora of 688 must have lasted three nights, and that the people who saw it and recorded it must have had butter for supper the night it was seen, which reflected the colour.

Geological Survey of Ireland, Connemara, Nov. 26

\section{Prismatic Structure in Ice}

THE following extracts from a letter from $\mathrm{Mr}$. Langton (whose name was, unfortunately, misread as Langters in sending his former letter to the press) may interest others as much as it has done myself, if space can be found for it in your columns. In that case, perhaps, you will kindly allow me to say a few words in reply on a future occasion.

St. John's College, Cambridge T. G. Bonney

"I admit with you that the prismatic structure of ice on the point of melting does not appear to have any connection with the hexagonal crystals in which it is formect; and that the great analogy between the conditions of ice in that state and of igneous rocks, and I may add of clay in the process of desiccation, seems to point to contraction as the common cause. But then arises the question whether ice really does contract as it approaches the melting-point, as we know that most melted mineral matter does on cooling, and clay on drying. I am quite willing to admit that it may do so, and that, as you observe, its demeanour at a point about $32^{\circ} \mathrm{F}$. has not been accurately ascertained; but if so, the fact should first be determined from independent observations before drawing conclusions from it. I am willing also to admit that I spoke loosely in my former letter when I said that the air bubbles in the process of freezing seemed to be formed in vertical lines. My object, in the concluding sentence of that letter, was to express a doubt as to there being any such contraction as youl suppose oin the ice approaching the melting-point, and to point out the lines of air bubbles as being the inmediate cause of the structure uf rotten ice. I did not then go into the origin of the bubbles, of into the cause of their being thus found in vertical lines. It in difficult to suppose that they were originally formed in those lines, for though it seems natural that the air, which is always containecl in water, should be exclucled on its crystallising, there does not appear to be any sufficient reason why the bubble cxcluded to-clay should be placed exactly under that formed yesterday. Upon reviewing the whole question, I am induced to think that, as will often happen, we were both right and both wrong : that you were right in attributing the prismatic structure originally io 